\title{
LABOR LAW, CLT AND THE 2017 BRAZILIAN LA- BOR REFORM ${ }^{1}$
}

João Renda Leal Fernandes ${ }^{2}$

\begin{abstract}
Labor Judge at the Tribunal Regional do Trabalho da $1^{\text {a }}$ Região (Rio de Janeiro Regional Labor Court). Post graduated in Public Law. Master's candidate in Labor Law and Social Security Law at the Universidade do Estado do Rio de Janeiro - UERJ (Rio de Janeiro State University). Former Exchange student at the Tokyo University of Foreign Studies (Tokyo, Japan)

E-mail: jrlfernandes@gmail.com
\end{abstract}

Received: 2018-01-22. Accepted:2018-03-14

\begin{abstract}
This study seeks to present to a foreign audience a brief description of the development of the Brazilian Labor Law, up to the Labor Reform approved by Law No. 13,467/2017, which significantly altered the nature of labor relations through amendments made to the texts of the "Consolidação das Leis do Trabalho - CLT" (Consolidation of Labor Laws - CLT), of Law No. 6,019/1974 and of other labor laws. The aim of this study is to analyze the Labor Reform within the historical context, with emphasis on its material aspects especially regarding the Collective Labor Law and Labor Union Law.
\end{abstract}

Keyword : Labor Reform - Law No. 13,467/2017 - Provisional Measure No. 808/2017 - CLT - Law No. 6,019/74 - Labor Law - Collective Labor Law - Union Law - Labor Courts - Outsourcing - Unions.

\section{THE INITIAL PHASE OF THE LABOR LAW IN BRAZIL (1888-1930) AND THE FIRST LEGISLATIVE STEPS}

Understanding the subject of this study initially requires a brief analysis of the historical evolution of Labor Law in Brazil.

1 Study presented at the "Brazil-Japan Litigation and Society Seminar: Courts and Dispute Resolution", University of Shinshu (Matsumoto, Nagano, Japan), January, 2018.

2 The author registers sincere acknowledgments to Celina Cantidiano and Christopher Burden for the valuable help and support in the translation to English Language and for the review of this work. 
It was only in 1888 , at the end of the Brazilian imperial period (1824-1889), that the so-called "Lei Aurea" (Imperial Law No. 3,353/1988 - the Law that decreed the end [...] of slavery in the country) completely abolished slavery in Brazil, which was the last independent country in America to abolish the institution (whereas, in the United States, for example, abolition occurred twenty-five years earlier).

The end of slavery gave way to the expansion and development of subordinate labor. And the following year (1889), the first Brazilian Republic was proclaimed.

However, contrary to what might be imagined, the establishment of the Brazilian Republic was not the result of a popular movement, but rather of a military coup carried out on November 15, 1889, which remains a national holiday in Brazil. The 1889 military takeover did not involve the broad participation of the people, who watched and observed the event largely as spectators.

The period between 1889 and 1930 is known as the "First Republic" or the "Old Republic", and was marked by strong economic liberalism and the concentration of political control in the hands of powerful agricultural groups. The Brazilian economy was based on agriculture, with a strong emphasis on exportation.

The first Republican Constitution - the second Constitution in the history of Brazil - dates back to the year $1891 .^{3}$ Some elements of the text of this Constitution deserve mention: the transition of the form of the government from monarchy to republic; the adoption of a presidential system of government; and the transformation of the State, from a unitary to a federal model.

In the "Old Republic" (1889-1930), political power, as already mentioned, was concentrated in the hands of the agricultural exporting elite.

Following the transference of power from the military to civilian representatives, in 1894, an alliance was forged between the agrarian oligarchies of the states of São Paulo and Minas Gerais, and politicians from these states began to alternate holding the office of Brazilian Presidency, in what was then known as the "Politica do Café com Leite" (the "Milk and Coffee Policy"), - due to the fact that the principal economic activity of São Paulo was coffee cultivation and that Minas Gerais dominated the dairy industry.

However, although political power was controlled by the agrarian elite, the liberal orthodoxy adopted in the economic sphere

3 The first Brazilian Constitution was granted in the year of 1824, by the Emperor at the time D. Pedro I, who had proclaimed the Independence in 1822, when he left the position of Prince Regent of the Portuguese Crown to self-proclaim himself as the first emperor of Brazil. Until nowadays, the Brazilian Constitutions date from the years of 1824, 1891, 1934, 1937, 1946, 1967, 1969 and 1988. 
- legally enshrined in the Civil Code of 1916 - made it possible to gradually expand the urban productive sector, with its industrial base and capitalist model. The industrial bourgeoisie, thus, began to acquire greater strength and economic importance. In the words of LUIZ WeRneCK Vianna, "in the political and social sphere, the dominance of agrarian exports did not create barriers to the emergence and prosperity of an industrial bourgeoisie"4.

Labor relations were essentially governed by the terms of the Location of Services Agreement, in accordance with the rules established by articles 1,216 and the following of the Civil Code of 1916.

However, it was in this period, between 1888 and 1930, that labor legislation began to make tentative inroads on specific and restricted topics. ${ }^{5}$ The first social security laws were also enacted at this time. ${ }^{6}$

\section{THE PERIOD AFTER 1930: CONFIRMATION OF THE LABOR LAW IN BRAZIL AND THE ORIGIN OF THE CONSOLIDATION OF LABOR LAWS (CLT) IN 1943}

In early 1930, in the midst of the global economic crisis, with a sharp fall in the price of coffee, conflicting political interests involving

4 VIANNA, Luiz Werneck. Liberalismo e sindicato no Brasil, 3. ed. Rio de Janeiro: Paz e Terra, 1978, p. 90.

5 As an example, in labor matters, we can quote some of the following legal documents: Decree No. 439/1890, with the "basis for organization of assistance to helpless childhood"; Decree No. 843/1890, granting advantages to the "Bank of Workers"; Decree No. 1,313/1891, that regulated the child's work; Decree No. 1,162/1890, which removed the criminal type of strike, maintaining as crime only the acts of violence practiced throughout the movement; Legislative Decree No. 1,150/1904, which granted facilities for the payment of debts of rural workers, benefit after extended to the urban workers (Legislative Decree No. 1,607/1906); Legislative Decree No. $1,637 / 1907$, which stated the creation of unions and cooperative companies; Decree No. 16,027/1923, that established the National Labor Council; Law No. 4,982/1925, which granted vacation (15 days per year) to the employees of commercial, industrial establishments and banks; Decree No. 17,934-A/1927, which enacted the Minor's Code, establishing the minimum age of 12 years old for work, besides the prohibition of the night work and in mines to the minors; Decree No. 5,492/1928, which regulated the work of the artists; Decree No. 5,746/1929, which amended the bankruptcy law, granting privileged status to the credits of "agents, employees and workers".

6 In the social security scope, it must be emphasized the Legislative Decree No. $3,724 / 1919$, on the mandatory insurance of work accidents; Law No. 4.682/1923 ("Law Eloy Chaves"), which determined the creation of the Retirement and Pension Fund for the railway workers, per company; and Law No. 5,109/1926, which extended the regime of the Law Eloy Chaves to port and maritime workers. 
the presidential succession led to a rupture in the alliance between the agrarian oligarchy of Minas Gerais and the coffee elite of São Paulo.

After refusing to accept the results of the presidential election held in March 1930, political forces from three Brazilian states (Minas Gerais, Rio Grande do Sul and Paraíba) joined together to forcibly install Getúlio Vargas, from the state of Rio Grande do Sul, as President of the Brazilian Republic.

This movement, composed of heterogeneous forces, marked the end of the "Politica do Café com Leite" ("Milk and Coffee Policy") and the so-called "First Republic".

Getúlio Vargas initially occupied the Brazilian Presidency from 1930 until 1945, during a period primarily marked by authoritarianism, an intense migratory flow of workers to the great cities, an increase in the population of urban centers, increasing industrial expansion and strict discipline and regulation of production factors, especially the industrial work force.

The establishment of a centralizing model, and state intervention in the economic sphere and in social relations, represented a break with liberal orthodoxy.

Although the movement of 1930 was not intended to enable the industrial bourgeoisie to seize political power, the interests of this economic class found support and encouragement in the prevailing political, economic and social scenario.

In 1930, the Ministry of Labor, Industry and Commerce was created. In 1931, an official union structure was established, based on the existence of a single union for each class of workers subject to recognition by the State and comprising an associate body of the State. The central government began to adopt concrete measures intended to encourage official unionism, while labor protests aimed at breaking with the officially-sanctioned union structure were repressed and suffocated. ${ }^{7}$

In 1932, an official system for resolving labor conflicts was founded, within the sphere of the Ministry of Labor, through the Labor Boards of Conciliation and Judgment, whereby only employees affiliated with official unions could lodge claims.

It was also this phase that saw the creation and regulation of the national minimum wage, the Social Security Card (a professional identification document still in use today), the limitation of the working day to eight (8) hours for commercial and industrial workers, and the establishment of annual paid vacation for certain classes of worker, among numerous other labor rights.

The period from 1930-1945 was marked by intense state

7 DELGADO, Mauricio Godinho. Curso de Direito do Trabalho, 11. ed. São Paulo: LTr, 2012, p. 110-111. 
administrative and legislative activity regarding the management of labor relations, with the institutionalization and confirmation of the Labor Law in Brazil.

The Professor of the University of Salamanca Manuel Carlos PAlomeque Lopez, in his classic book "Labor Law and Ideology", emphasizes the ambivalent character of the Labor Law: at the same time that it represents a "victory" for the working class - consistent with material improvements in living and working conditions - it is also the result of a "concession" from the State and the bourgeoisie, intended to create apparent harmony between social classes with different interests, thus avoiding the true emancipation of the working class and enabling the continued existence and conservation of capitalism. ${ }^{8}$

BERNARD EDELMAN is more emphatic, in demystifying the view that the Labor Law was the result of a "long series of victories" on the part of the working class. According to the French Professor, these "victories" represented political "losses" that concealed the servile and submissive condition of working people in relation to those who control capital and the means of production. ${ }^{9}$

Moreover, in Brazil, the regulation of labor relations ended up masking and mitigating conflicts between social classes with different interests and, as a result, created an environment suitable for the country's modernization, through economic development and the expansion of industrial capitalism.

The government of President Getúlio Vargas invested heavily in propaganda. This official propaganda associated the President's image of Brazilian President with the protection of the workers and the creation of new labor rights. This helped contribute to Vargas's continuance in political power for such a long time, from 1930 until 1945, and again from 1951 until 1954.

During this period, the Government organized annual parades on the $1^{\text {st }}$ of May (International Workers' Day) to announce new legislation concerning labor issues. These parades often took place at prominent venues, such as soccer stadiums. The world famous Maracanã stadium was not built until the Soccer World Cup of 1950, so the parades used to take place at the football stadium of Rio de Janeiro soccer team, Vasco da Gama, (the São Januário Stadium) or in the Castelo neighborhood (in downtown Rio).

In 1942, Vargas created a commission of top lawyers and professors to prepare a bill for the creation of a Unified Code of Labor Relations.

8 PALOMEQUE LOPEZ, Manuel Carlos. Direito do Trabalho e ideologia. Coimbra: Almedina, 2001, p. 123.

9 EDELMAN, Bernard. A legalização da classe operária. Trad. Marcus Orione. São Paulo: Boitempo, 2016, p. 8. 
The most important development of this era was the enactment, by President Getúlio Vargas, of the "Consolidação das Leis do Trabalho - CLT" (Consolidation of Labor Laws) (Decree-Law No. 5,452/1943) on May $1^{\text {st }}, 1943$.

The CLT sought to unite and structure, in a single codified document, all the existing labor laws, in addition to regulating new issues concerning labor relations, and the procedural rules to be applied in the resolution of labor conflicts.

The CLT rules underwent hundreds of changes over the decades, and despite occasional additional legislation (separate laws approved over the years), the Consolidation of Labor Laws (CLT) remains the most important legal document for regulating labor relations, and establishing procedural rules for the resolution of labor conflicts, in Brazil.

The CLT has persisted throughout many challenging periods of Brazilian history: the democratic period of 1945-1964; the military dictatorship imposed in 1964 (which lasted until 1985); the transition to democracy in the 1980's; and the democratic stabilization following the drafting of the 1988 Constitution. Although the CLT has been amended on multiple occasions, it may be said that the basic rules of Brazilian Labor Law and Procedural Labor Law remain essentially based on the concepts and legal institutions established by the CLT and some other laws.

\section{THE 1988 CONSTITUTION AND THE EXCLUSIVE COMPETENCE OF THE CENTRAL GOVERNMENT TO LEGISLATE ON LABOR LAW AND PROCEDURAL LABOR LAW}

The Constitution currently in force in Brazil was drafted in 1988, during the transition to democracy following more than two decades of military dictatorship (1964-1985). On October 5, 2018, this Constitution will celebrate the $30^{\text {th }}$ anniversary of its enactment.

Over the course of these 30 years, the consensus regarding the effectiveness, normative force and binding character of the rules expressed in the constitutional text has been consolidated.

Every field of Brazilian law has since been read and interpreted according to the rules and principles of the 1988 Constitution, including our Labor Law and Procedural Labor Law. The mechanisms for ensuring the constitutionality of the laws have been consolidated and improved throughout these 30 years since the Constitution became effective. Some matters concerning the constitutionality of certain laws or legal rules have attracted the attention of the Brazilian public in 
recent years. $^{10}$

The text of the 1988 Constitution is extensive and guarantees a long list of social rights, including numerous labor rights.

An important aspect of Brazilian constitutional history must be noted here: the federalist form of the organization of the State (with its division into different federal states), adopted with the Constitution of 1891 (which was strongly influenced by the North American constitutional experience). However, unlike the USA, Brazil has a long centralizing tradition, with power concentrated in the hands of a central government (initially, that of the Portuguese crown, and, following the proclamation of Independence, in 1822, of the Emperors).

In other words, in Brazil, it was not the case that previously independent states decided to join a union of federal states. The tendency was actually in the opposite direction, with the State - previously a centralizing power - proceeding to delegate competences and powers to the federal states. In the words of the Supreme Court Jutice, Luís RoBerto BARroso, "the federalist formula adopted, inspired by the North American model, ignored the country's centralizing past". ${ }^{11}$

This continues to affect the rules of Brazilian Labor Law and Procedural Labor Law, whose legislative competence continues to be the preserve of the Union (in practice, the Federal Government and the National Congress). Which is to say, in a country of continental dimensions, with highly diverse economic and social realities, the Union (the Federal Government and National Congress) continues to enjoy exclusive legislative competence to enact rules concerning Labor Courts and Procedural Labor Law, effective throughout Brazil.

In this regard, it is worth verifying the current text of the 1988 Constitution:

Article 22. The Union has the exclusive power to legislate on:

10 Nowadays, in Brazil, the Supreme Court is daily in the newspapers and many judgments may be accompanied live through the television. Matters involving subjects as the homoaffective union, research with embryonic stem cells, rules of prescription (limitation period) to legally claim as to mandatory collections to the FGTS (Workers Severance Guarantee Fund), "unretirement" (possibility of review in the value of social security benefits paid by the Social Security Public System) and criminal cases involving the high level of the government started to receive more highlight in the television, press and digital media. Currently, many Brazilians discuss, in the streets and bars, the decisions of the Supreme Court. Its eleven (11) Justices became well known to ordinary people who read magazines, newspapers and watch TV news.

11 BARROSO, Luís Roberto. O direito constitucional e a efetividade de suas normas, 6 . ed. atualizada. Rio de Janeiro: Renovar, 2002, p. 15. 
I-civil, commercial, criminal, procedural, electoral, agrarian, maritime, aeronautical, space and labor law; (...)

As can be seen, the federal states and the municipalities may not, in principle, enact general additions to the Labor Law and Procedural Labor Law. In Brazil, competence for the creation of laws on these matters - to be effective throughout Brazil - is exclusively federal, which is to say, it is basically concentrated in the hands of the Brazilian President and the members of the National Congress (Senators and Federal Deputies).

Since the 1988 Constitution has been in effect, labor legislation has been expanded and improved, with the enactment of numerous laws and specific amendments, the modernization of previous laws (including the CLT) and, generally speaking, with intense state regulation regarding the nature of labor relations. Below follow some examples of legislation enacted in recent years:

- New Internships Law (Law No. 11,788, of September 25, 2008), which broadly regulates the relations of paid and nonpaid student internships;

- Law of Proportional Prior Notice (Law No. 12,506, of October 11, 2011), which established the period of prior notice. According to this Law, an employee who has worked at the same company for 20 years has the right to prior notice of 90 days if dismissed without cause;

- Constitutional Amendment No. 72, of April 2, 2012, and Supplementary Law No. 150 of June 1, 2015, which extended to domestic employees' numerous rights, such as the limitation on the number of hours worked per day and per week, the compulsory payment of FGTS (Workers Severance Guarantee Fund) by domestic employers, and compensation for night work at higher rates than day work, among other benefits.

\section{THE BRAZILIAN LABOR COURT SYSTEM}

In parallel with the establishment and consolidation of Labor Law in Brazil, a specialist body for the resolution of labor conflicts was developed within the judiciary. In 1946, the Labor Courts stopped operating at the administrative level of the Ministry of Labor (a branch of the Executive Authority) and proceeded to form part of the Judicial Branch, thus, becoming independent.

Since then, this field has grown and developed significantly, and its existence is currently defined and regulated by articles 111 to 116 of the 1988 Constitution. 
The Labor Court System (the Brazilian Federalized Labor Court System) currently comprises the Superior Labor Court, headquartered in the Federal District (Brasília) and 24 Regional Labor Courts. In 2016, the Brazilian Labor Court System also comprised a total of 1,572 functioning Labor Courts, 3,668 Labor Judges, 41,942 public servants and 10,701 assistants (outsourced and interns). ${ }^{12}$ In the year 2016 alone, the Labor Courts received 3,700,642 new cases for judgment, in addition to the cases remaining from previous years. ${ }^{13}$

In the year 2017, the process of implementing the electronic procedural system was concluded in all the Labor Courts of the country. Which is to say, currently, all the suits filed before the Brazilian Labor Courts have their files stored in an electronic procedural data storage system, and no longer physically on paper. ${ }^{14}$ This means that proceedings are all filed and analyzed using computer records, available to any device that has Internet access.

According to article 114 of the Constitution, the Brazilian Labor Court System (Brazilian Federalized Labor Court System) has competence to evaluate individual and collective labor conflicts, and conflicts relating to strikes and collective bargaining between the unions of employers and employees.

\section{ECONOMIC CRISIS, SOCIAL TRANSFORMATION AND THE NEW ASCENDANCY OF LIBERAL IDEOLOGY}

Since the final decades of the $20^{\text {th }}$ Century, many countries have seen a return to liberal ideals.

In some of the main centers of the capitalist system, the elections of Margaret Thatcher (in England, in 1979), Ronald Reagan (in the US, in 1980) and Helmut Kohl (in Germany, in 1982) clearly showed political victories of this liberal ideology. These victories marked the rise in power of a deregulatory approach to the Welfare State.

In the 1990s, Brazil also adopted this tendency, which supports reduced state intervention in the economic domain. This was seen, in different ways and on different levels, in the governments of Presidents Fernando Collor de Melo (1990-1992), Itamar Franco (1992-1994) and Fernando Henrique Cardoso (1995-2002).

However, in Brazil, this liberal tendency diminished during a

12 CONSELHO NACIONAL DE JUSTIÇA. Justiça em números 2017: ano-base 2016. Brasília: CNJ, 2017, pp. 28-40.

13 TRIBUNAL SUPERIOR DO TRABALHO, Coordenadoria de Estatística e Pesquisa. Relatório geral da Justiça do Trabalho 2016. Brasília: TST, 2017.

14 TRIBUNAL SUPERIOR DO TRABALHO, Notícias do TST. "Processos recebidos na Justiça do Trabalho já são 100\% eletrônicos". Available at http://www.tst.jus.br/noticias/-/ asset_publisher/89Dk/content/id/24446854. Access on October 20, 2017. 
period of more than 13 years, under the government of President Lula's Workers' Party and that of his successor Dilma Roussef.

But, since May 2016, when President Rousseff was impeached and Michel Temer became President, there has been a marked resumption of liberal policy, which argues for reduced state intervention in the economy and the carrying out of structural reforms, such as the Labor Reform and the Pension Reform.

The return of this tendency is undoubtedly the result of ongoing political and economic transformations affecting Brazilian society, such as the ageing of its population, the economic-financial crisis and the increase in the unemployment rate in recent years, the need to balance public accounts (especially regarding the social security system), the need for Brazilian companies to be able to compete with competitors on a global scale, technological innovations that have resulted in job losses, and the creation of new forms of work (home offices and work provided by companies existing only in digital form, such as Uber).

In the first half of 2017, the government of Michel Temer was in a hurry to get a Labor Reform bill passed in the National Congress. Favored by a fleeting parliamentary majority, the government managed to secure swift approval for broad, sweeping reforms to the CLT and other specific labor laws. This Labor Reform resulted in significant changes to the rules of the Labor Law and Procedural Labor Law.

The ease with which the Labor Reform bill was passed was due to the fact that the CLT and the majority of the labor laws have the status of ordinary laws. So, in the National Congress, amendments do not require high or qualified quorums to open hearings or pass bills. In this regard, article 47 of the 1988 Constitution states:

Article 47. Except where there is a constitutional provision to the contrary, the decisions of each House and of their committees shall be taken by a majority vote, when the absolute majority of its members are present.

The Pension Reform bill which the Government is still trying to approve, however, has encountered more difficulties in its passage to becoming law, since it seeks to alter certain constitutional provisions, which requires amending the text of the Constitution, necessitating the approval of the proposal by three fifths of the members of the House of Representatives and Federal Senate, in two series of votes in each of the Legislative Houses.

On the Proposals for Constitutional Amendments, article 60, paragraph 2, of the 1988 Constitution states as follows: 
Article 60. (...) Paragraph 2. The proposal shall be discussed and voted upon in each House of the National Congress, in two readings, and it shall be considered approved if it obtains in both readings, three-fifths of the votes of the respective members.

The Labor Reform bill was approved through Ordinary Law No. 13,467, of July 13, 2017, becoming effective 120 days after its publication (which is to say, on November 11, 2017).

\section{THE LABOR REFORM LAW (ORDINARY LAW NO. $13,467 / 2017)$}

As previously discussed, unlike the Pension Reform, the Labor Reform bill was approved with relative ease in the National Congress, due to the fact that the CLT has the status of an ordinary law, whose amendment did not require approval by special or high quorums of parliamentarians.

Favored by the momentary support of a majority of parliamentarians, the government of President Michel Temer undertook to make significant changes to the CLT and certain other specific labor laws, the President's declaring that it would be necessary to "update" supposedly "old" and "outdated" legislation, to adapt it to the present time, in order to create jobs, and generate income and economic growth. Labor Judge Marlos Augusto MeleK formed part of a commission that helped draft the text of the new law. In his book, MELEK criticized the existence of the "anachronistic, old CLT which refers to 'typing', when we live in an age of 'smart phones'15.

However, the haste with which the Labor Reform bill was discussed in the House of Representatives and Federal Senate, and several incongruities and possible unconstitutionalities in its text, have been strongly criticized by Brazilian jurists. Law No. 13,467/2017 amended over a hundred different items of the CLT, so it certainly deserved a more careful and considered debate, with broader discussions involving representatives of both workers and companies, and a debate with the general public. Unfortunately, this did not happen.

The Labor Reform bill (Bill No. 6,787) was presented by the Executive Branch on December 23, 2016 and was effectively discussed in Parliament for a period of, approximately, only four months. After being approved by the House of Representatives, the Federal Senate did not amend any provisions of the bill thus enabling the swift approval and enactment of the new law.

15 MELEK, Marlos Augusto. Trabalhista! E agora? Onde as empresas mais erram. Curitiba: Estudo Imediato, 2016, p. 19. 
In addition to this, the Labor Reform Law text stated that it would come into in effect after 120 days counted from the date of its publication, which constitutes a very short period of adaption, when compared to other laws of major importance and social consequence.

As if this were not enough, on November 14, 2017 (which is to say, less than a week after the new law came into effect), the Brazilian President issued Provisional Measure No. 808/2017, with new changes to aspects of the CLT that already had been amended by Law No. $13,467 / 2017$.

As can be seen, the new government took advantage of the favorable political moment to approve, with obvious haste, significant changes to the Labor Law and Procedural Labor Law.

In this study, we intend to undertake an empirical and timely analysis of some of the main aspects of the Labor Reform Law, with particular emphasis on changes directly concerning the regulations of the Collective Labor Law and Union Law. We will also cite some amendments made to the Individual Labor Law that also have repercussions in the collective sphere.

As previously observed the reform was broad and amended the CLT in several areas. This study obviously does not intend to undertake a comprehensive analysis of the reform, but rather seeks to provide the foreign reader with a brief overview of some important and controversial points whose regulation was amended by Law No. 13,467/2017.

The significant changes made to the rules of the Procedural Labor Law will not be the object of the analysis of this brief study.

\subsection{Collective bargaining agreements and collective agreements prevail over state legislation (article 611-A of the CLT)}

The liberal character of the Labor Reform bill is clear in the many provisions that seek to prioritize clauses stipulated by contracting parties over those of the CLT and state legislation. This is referred to as the "prevalence of the negotiated over the legislated".

Within the scope of the Union Law, the 1988 Constitution and the CLT assert the existence of two types of agreements arising from collective negotiations: the collective bargaining agreement (a written agreement signed between the workers' union and the union representing the employers) and the collective agreement (a written agreement directly entered into by the workers' union and one or more companies).

These collective bargaining agreements and collective agreements create legal rules that regulate employment contracts. However, the courts and the jurists' opinions have historically imposed limitations on the terms that could be freely negotiated through these 
collective arrangements, establishing a series of restrictions regarding non-negotiable rights, which cannot be the object of waivers or settlements by the parties, either in individual or collective agreements.

As an example, we cite the minimum 1 hour work break for rest and meals of article 71, of the CLT, for continuous work lasting more than 6 hours, commonly referred as the "meal and rest break".

The idea has long prevailed that this interval could not be eliminated or reduced, even through collective or collective bargaining agreements, since it concerns an irrevocable right, directly related to occupational health.

Regarding this, Judicial Precedent No. 437, II, of the Superior Labor Court stated that this 1 hour minimum break was non-negotiable, even through collective negotiation involving the workers' union:

II-Anyclause of a collective agreement or collective
bargaining agreement concerning the elimination
or reduction of the work break for rest and meals
is invalid, because it constitutes a hygiene, health
and work safety measure, guaranteed by the rule
of public order (article 71 of the CLT and article
7, XXII, of the 1988 Constitution), and is not
susceptible to collective negotiation.

However, following the Labor Reform, Article 611-A of the CLT states that the clauses of collective arrangements shall prevail over state legislation when regarding, among other subjects, work breaks, while respecting the minimum limit of 30 minutes for shifts longer than six hours.

In contrast to the text cited in Judicial Precedent No. 437 of TST (Brazilian Superior Labor Court), article 611-A of CLT proceeded to provide for the possibility of a reduction, through a collective bargaining agreement or collective agreement, of the work break for meals and rest, while respecting the minimum limit of 30 minutes for shifts longer than six hours. In other words, although article 71 of the CLT states the mandatory granting of a minimum interval of 1 hour for shifts longer than six hours, following the passing of the Labor Reform bill, article 611-A of the CLT established the possibility of reducing this interval if there were an agreement with the workers' union. The CLT is now effective with the following wording:

Article 611-A. Collective bargaining agreements and collective agreements, in observance of items III and VI of the head provision of article 8 of the Constitution, shall prevail over the law when 
concerning, among other things, the following matters: (wording provided by Provisional Measure No. 808, de 2017) (...)

III - work breaks for rest and meals, respecting a minimum limit of thirty minutes for shifts longer than six hours; (...)

Other examples of matters that can be negotiated through collective bargaining agreements or collective agreements, as expressly provided for by article 611-A of the CLT, include: payment of overtime through annual offsetting of overtime (the extra hours worked can be compensated by reducing the shift or granting other days off, and this compensation must occur within a period of up to one year); identification of positions of trust, without the need to control working hours (which is to say, those positions considered as management and administrative posts, with the possibility of limited work breaks and unlimited overtime); home office, on-call systems and intermittent work (zerohours contracts); time control systems (decisions about the working hours recording system: if working hours shall be recorded through manual notes on time sheets, clocking in and out systems, electronic systems, biometrical systems, etc); holiday date flexibility (changing of dates of holidays); the selection of employees' representatives in the workplace, among other subjects.

It is emphasized that, due to the use of the expression "among others" in the text of the law, the list of matters of article 611-A of CLT has a merely exemplary character, which is to say, other matters besides the ones listed in the law have also become the object of free stipulation in collective bargaining agreements and collective agreements.

By contrast, article 611-B of the CLT was also introduced, which provides a complete list of those rights that may not be suppressed or reduced through collective bargaining agreements and collective agreements (notably those rights ensured in article 7 of the Constitution). It must be observed, in this regard, that the law uses the expression "exclusively". This means that the list of subjects is comprehensive, which is to say, only those matters covered by article 611-B may not be the object of collective rules. According to the text of the law, this allows all other matters not listed in article 611-B to be freely negotiated through collective agreements or collective bargaining agreements.

\subsection{Individual agreements prevail over state legislation (CLT, article 444, sole paragraph)}

The liberal idea that prioritizes free will also gave rise to the 
insertion of article 444, sole paragraph, of the CLT. These new resolutions state, in individual labor agreements, that clauses established directly between employees and employers prevail over the provisions of state legislation regarding the same matters listed in article 611-A. However, this will only be possible in cases where the employee has a university degree and receives a monthly salary equal to, or greater than, twice the value of the highest pension benefit paid by the Public Social Security System.

In practice, this means greater freedom for inserting clauses in agreements entered into by employees who are college graduates and have a monthly salary equal to, or higher than, approximately US\$3,200, according to the exchange rates currently in force (December/2017). The agreements of these employees may, for example, indicate a reduction in the work break for rest and meals (respecting the minimum limit of 30 minutes), the adoption of annual offsetting of overtime (with the compensation of overtime within a period of up to one year) and the altering of holiday dates.

The cited article 444, of the CLT, is now effective with the following wording:

Article 444 - Contractual working relationships may be the object of free stipulation by the interested parties concerning everything that does not contravene protective work provisions, collective arrangements that are applicable thereto and the decisions of the competent authorities.

Sole paragraph. The free stipulation referred to in the head provision of this article applies to the hypothesis stated in article 611-A of this Consolidation, with the same legal efficacy and prevalence over the collective arrangements, if the employee holds a university degree certificate and receives a monthly salary equal to, or higher than, twice the maximum limit of the benefits of the Public Social Security System. (Included by Law No. 13,467/2017)

\subsection{Offsetting of overtime through individual written agreements (CLT, article 59, §5)}

Law No. 13,467/2017 included, in article 59 of CLT, a new paragraph (§5), to assert the possibility of stipulation, through individual 
written agreements between employees and employers, for offsetting overtime, providing that such compensation occurs within a maximum period of 6 months.

\subsection{The $12 \times 36$ working hour system (12 hours of work and 36 hours of rest) through individual agreements of professionals in the health sector (article 59-A of CLT)}

In some sectors of the Brazilian economy, it is common to adopt a scale of 12 working hours for 36 hours of rest (" $12 \times 36$ "). In this system, a worker, for example, works from 7:00 a.m. to 7:00 p.m. (or from 7:00 p.m. to 7:00 a.m. the day after), followed by 36 hours of rest. This shift is often adopted by doormen, security guards, watchmen, and professionals from the health sector (nursing technicians, nurses, physiotherapists, and doctors, among other).

By considering a daily shift of 12 working hours (longer than the normal 8 working day indicated in article 7, XIII, of the Constitution), the notion prevails that the adoption of such a system was only valid when authorized by the law or when foreseen in a collective agreement or collective bargaining agreement (in this sense, Judicial Precedent No. 444, of TST).

Law No. 13,467/2017, however, inserted article 59-A into the CLT, whose text now allows the adoption of this system through a simple provision in an individual agreement entered into between an employer and employee.

Provisional Measure No. 808/2017, however, again required express provision in a collective rule (collective agreement or collective bargaining agreement) for the adoption of such a system, except regarding entities operating in the health sector (article 59-A, §2, of CLT).

Which is to say, as a rule, the validity of the adoption of the $12 \times 36$ scale continues to depend on provision being made in the collective agreement or collective bargaining agreement, with a requirement for the participation of the workers' union in the negotiations.

According to the new text of the CLT, an exception occurs regarding professionals who perform their work in hospitals, clinics or other institutions of the health sector (nursing technicians, nurses, physiotherapists, and doctors, among others), where the adoption of the $12 \times 36$ scale is now valid on a simple provision being made in the individual agreement entered into between employee and employer.

\subsection{Collective agreements (entered into between the company and the union) prevail over the collective bargaining agreements}


As previously seen, the collective arrangements stated in the Constitution and in the CLT are the collective bargaining agreement (an agreement between the workers' union and the union representative of the companies) and the collective agreement (an agreement executed directly by the workers' union with one or more companies).

Before the Labor Reform bill, article 620 of the CLT stated that "the conditions established in collective bargaining agreements, when more favorable, shall prevail over those established in the collective agreement". By using the expression "when more favorable", the law privileged the principle of the most favorable rule, concluding that the collective agreement and the collective bargaining agreement should be analyzed together, in a global form, to verify which is more favorable and should prevail in a certain specific case.

However, the new wording of article 620, established by Law No. $13,467 / 2017$, is as follows:

Article 620. The conditions established in the collective labor agreement shall always prevail over those established in the collective labor bargaining agreement.

The new rule contrasts with the previous one, by stating that the collective agreement shall "always" prevail over the collective bargaining agreement.

The application of this new provision may lead to intense discussion in the Brazilian courts, especially when the collective agreement is less favorable than the collective bargaining agreement or when it limits or suppresses labor rights.

Gustavo Filipe Barbosa Garcia argues that the principle of the application of the most favorable rule should continue to prevail, due to the principle of protection guaranteed in the constitutional text:

The provision resulting from Law 13,467/2017 may be contrary to the principle of the most favorable rule, which arises from the principle of protection, enshrined at the constitutional level (article 7, head provision, of the Federal Constitution of 1988).

Thus, the constitutional interpretation shows that the conditions established in the collective labor agreement (always) prevail over those established in the collective labor bargaining agreement, 
but providing that those of the collective labor agreement generate more benefits than those of the collective labor bargaining agreement.

Therefore, if the provisions of the collective labor bargaining agreement are more favorable, the constitutional understanding is that it should prevail. ${ }^{16}$

As can be seen, in the light of the constitutional rules, the interpretation of this provision may also generate broad discussion among jurists and in the Labor Courts.

\subsection{Prohibition of the subsisting consequences of the rules of collective agreements and collective bargaining agreements (article 614, §3, of the CLT)}

This discussion concerns the efficacy of the rules stated in collective bargaining agreements and collective agreements even after the expiry of their period of effectiveness.

According to article $614, \S 3$, of the CLT, the maximum period of effectiveness of a collective agreement or collective bargaining agreement is 2 years.

However, the negotiations undertaken with a workers' union for the execution of a new agreement is often extended until after the termination of the effectiveness of the previous agreement. In such a case, the effective term of the previous agreement has already expired but the parties have not yet agreed the terms for the drawing up of a new agreement.

Regarding this matter, since the year 2012, Judicial Precedent No. 277 of the TST (Brazilian Superior Labor Court) has stated that "the clauses of collective agreements or of collective bargaining agreements form part of individual employment agreements and shall only be modified or suppressed as a result of collective labor negotiation".

Contradicting this understanding, Law No. 13,467/2017 amended article 614, $\S 3$, of the CLT, to prohibit the subsisting consequences of rules asserted in collective agreements or collective bargaining agreements:

Article 614. (...) \$3. It shall not be permitted to stipulate the duration of a collective bargaining

16 GARCIA, Gustavo Filipe Barbosa. Reforma trabalhista, 2. ed. Salvador: Juspodivm, 2017, p. 294. 
agreement or collective agreement of more than two years, thus prohibiting subsisting consequences. (wording given in Law No. 13,467/2017).

In other words, in opposition to Judicial Precedent No. 277 of the TST, it was sought to prevent the production of effects of collective rules or collective agreements beyond the term of their effectiveness.

\subsection{Indispensable party necessary in actions that seek a declaration of nullity of clauses of collective agreements or collective bargaining agreements (article 611-A, §5, of CLT)}

Initially, Law No. 13,467/2017 introduced into the CLT a provision that, in individual or class actions which sought to render invalid clauses of collective bargaining agreements or collective agreements, the workers' union should mandatorily be summoned to participate as an indispensable party (article 611-A, §5). Which is to say, if in the judicial action a worker sought - even incidentally or among other requests - the declaration of nullity of the clause agreed by the union representative of its professional category, this union should also be invited to participate in the process.

However, this provision (article 611-A, §5) was amended through Provisional Measure No. 808/2017, in the following terms:

Article 611-A. (...) \$5. The union subscribers to collective bargaining agreements or to collective labor agreements shall participate, as indispensable parties, in class actions intended to annul clauses of these agreements, its being prohibited to appreciate individual actions. (Wording given by Provisional Measure No. 808/2017)

This new wording provides that it is only in class actions seeking the invalidation of clauses of collective bargaining agreements or collective agreements, that the union of the professional class shall be mandatorily summoned to participate as an indispensable party.

The final part of the provision prohibits the appreciation - even incidentally - of the validity of the clause of the agreement or the collective bargaining agreement in individual actions filed by a given worker, which, from our point of view, violates the principle of access to justice and judicial review provided for in article 5, item XXXV, of the Constitution. According to its current wording (determined by Provisional Measure No. 808/2017), the constitutionality of this 
provision is questionable and will lead to intense debate in the Brazilian Courts and among jurists.

\subsection{Arbitration to resolve individual labor disputes (article 507-A of the CLT)}

Article 507-A, incorporated into the CLT by Law No. $13,467 / 2017$, proceeded to consider the possibility of an arbitration clause in individual labor agreements providing that the resolution of conflicts between the parties (employee and employer) occurs by means of arbitration, and provided that the presence of this clause arises from the initiative of the employee him/herself or enjoys his/her express agreement.

According to article 507-A, the existence of an arbitration clause is only allowed when the employee receives a monthly salary equal to, or greater than, twice the highest value of the social security benefit paid by the Public Social Security System (in other words, equal to or higher than approximately US\$ 3,200 by current values).

It is noteworthy that, in contrast to the provision of article 444, sole paragraph, article 507-A does not require that an employee have a college degree in order to insert an arbitration clause.

Article 507-A offers no other provision regarding which party shall bear the cost of the establishment and realization of the arbitration.

Furthermore, the provision regarding the possibility of the resolution of individual labor conflicts by means of arbitration shall be questioned before the Brazilian Courts, because the Arbitration Law (Law No. 9,307/1996) itself states that only conflicts concerning freely transferable property rights may be settled through this alternative method of dispute resolution.

For this reason, regarding the Labor Reform bill, the prevailing understanding in the courts was that arbitration should be allowed only for the resolution of collective labor conflicts, but was incompatible with the resolution of individual conflicts. Subsection I for Individual Conflicts of the TST expressly adopted this understanding. ${ }^{17}$

As asserted by HOMERo BATISTA, "there will be great judicial controversy in this regard, considering that, in similar cases, the Labor Courts did not accept this alternative form of conflict resolution on the understanding that labor credits are defined as unwaivable rights, being adverse to arbitration as stated in Law No. 9,307/1996". ${ }^{18}$

17 TST (Brazilian Superior Labor Court), SBDI-I, E-ED-RR-79500-61.2006.5.05.0028, Labor Justice Rapporteur: João Batista Brito Pereira, DEJT: March 30, 2010.

18 SILVA, Homero Batista Mateus da. Comentários à reforma trabalhista. São Paulo: Editora Revista dos Tribunais, 2017, p. 70. 


\subsection{Union ratification is no longer mandatory in the termination of employment contracts already in force for more than 1 year (revocation of article $477, \S 1$, of the CLT)}

Paragraph 1 of article 477 of the CLT was revoked by Law No. 13,467/2017. This provision stated that a resignation request or receipt of a release agreement from an employment contract, signed by an employee who had provided more than one year of service to the company, would only be valid when made with the assistance of the respective union of the professional class or under the authority of the Ministry of Labor.

Thus, there is no longer any need for assistance by the union in the termination of the employment contracts of employees who have provided more than one year of service to the same employer.

\subsection{Ratification of extrajudicial agreements (article 855-B and the following of the CLT)}

The Labor Reform bill inserted an additional chapter into the CLT, which stated the possibility of approval, in the Labor Courts, of extrajudicial agreements entered into between the parties.

In order to avoid possible frauds, especially in cases of individual agreements, article 855-B states that the parties may not be represented by the same lawyer. It also states that the employee, if he chooses, may be assisted by the lawyer of the workers' union.

A petition where approval of the extrajudicial agreement is required suspends the statute of limitation of the action regarding the rights specified therein (article 855-E of the CLT).

\subsection{Elimination of mandatory union dues}

Mandatory union dues used to be payable every year. According to Gustavo Filipe Barbosa Garcia, this obligation "restricted freedom of association (labor union freedom) and was incompatible with the ILO Convention 87, as said duty was owed regardless of any declared intent or agreement between the employee or employer, or affiliation with the union."'19

Companies were required to deduct from their employees' payroll the sum equivalent to one day's salary every March (as stated in former articles 580 and 582 of CLT).

Employers' union dues also had to be paid every January (article

19 GARCIA, Gustavo Filipe Barbosa. Op. cit, p. 223. 
587, CLT).

The novelty introduced by the Labor Reform bill, in this regard, was the abolition of the mandatory payment of such union dues, which no longer have the status of a tax and are now optional and voluntary. By changing articles 578, 579, 582, 583, 587 and 602 of the CLT, Law No. 13,467/2017 states that union dues will only be payable upon prior and express authorization by workers and companies. In other words, the Labor Reform bill has put an end to annual mandatory union dues.

In this same regard, article 611-B, XXVI, CLT, expressly prohibits clauses in collective bargaining agreements or collective labor agreements providing for the payment of union dues.

The aim is for unions to be supported exclusively by optional and voluntary contributions previously authorized by their members, in accordance with the idea of freedom of association.

However, while the Labor Reform has granted greater powers and responsibilities to Brazilian unions (particularly with regard to the prevalence of clauses in collective bargaining agreements or collective labor agreements over state legislation, as per article 611-A, CLT), the cessation of this source of income may create serious financial problems for the unions, which have received annual union dues since the 1930's (the Vargas Period). ${ }^{20}$

To allow for a period of adjustment to the new rules, many people expected that the President would later enact, by means of a Provisional Measure, a transitional rule providing for the gradual termination of said union dues. Provisional Measure No. 808/2017, however, did not contemplate any such thing. Therefore, the payment of mandatory union dues was summarily terminated.

Although the ending of mandatory union dues represents progress regarding freedom of association, Brazil has unfortunately not ratified the ILO Convention 87 and the centralized union regime remains in force in Brazil.

\subsection{The annual certificate of discharge before the employee's union (article 507-B of the CLT)}

The inclusion of article 507-B in the CLT allows employers and

20 Platon Neto defended that the end of mandatory union dues should be gradual and slow, so that unions would have a period of adaptation to new ways of supporting their activities. He stated also "that the immediate removal of mandatory union dues will be extremely cruel to the union system and that the ideal scenario would be its gradual termination, so that it would end within three years, minimum, or five years maximum." [AZEVEDO NETO, Platon Teixeira de. (Comentários ao art. 578 da CLT). In: RODRIGUES, Deusmar José (Coord.). Lei da reforma trabalhista: comentada artigo por artigo. Leme/SP: JH Mizuno, 2017, p. 223]. 
employees to call on the assistance of the union to secure an annual general release agreement regarding labor obligations. The new article states the following:

Article 507-B. Employees and employers may, during the term, or following termination, of an employment contract, sign an annual agreement of release from labor obligations before the workers union.

Sole Paragraph. The agreement shall specify the monthly obligations fulfilled and shall include the annual release granted by the employee, effective for the release from the sums specified therein.

As has been observed, the assistance of the unions in the termination of employment contracts effective for more than one year is no longer necessary, due to the repeal of article 477, paragraph 1, of the CLT. However, the Labor Reform law now provides for the assistance of the unions in the execution of an "annual release agreement regarding labor obligations". And the law states that this agreement "is effective regarding release from the sums specified therein". In other words, the sums listed in said release agreement (e.g., vacation, thirteenth salary, FGTS, profit sharing, transportation vouchers, meal tickets, etc) cannot, in principle, be subsequently challenged and claimed by employees, even if the sums have been paid incorrectly.

Most employees - as they are subject to the employer's rules, due to their economic subordination and fear of losing their jobs - will have little power to refuse or question their employers when invited to sign such release agreements before the unions. This fact will likely give rise to discussions regarding effective freedom and absence of coercion or consent by the employee in the execution of said release agreements.

The annual release agreement cannot serve as some kind of pretext for granting remission or forgiveness to defaulting employers who incorrectly perform labor obligations guaranteed by the law or Constitution.

According to Vólia BOMfIM CASSAR,

the possibility of an annual release regarding every payment mentioned in the agreement, during the term of the employment contract, when the employee is under the employer's rules, raises questions about free will. In fact, if the receipts are sufficient 
to prove compliance with labor obligations, what is the reason for the release regarding the union? Clearly, the intention is to secure a general release for unpaid amounts, which leads to unjust enrichment. Thus, the effectiveness of the annual release before the union must be discussed. ${ }^{21}$

As can be seen, the new provision included in article 507-B of the CLT has already come under severe criticism from jurists. DANIEL LisBôA is even more critical in arguing for the unconstitutionality of this article:

At the employee's expense, the 'annual labor release agreement' imposes an implicit waiver on rights, as it places the employee in a worse situation than provided for by civil legislation in contracts in general.

By authorizing the implicit waiver in the release, the reforming legislator created a legal situation worse than the previous one and worse than the situation provided for by civil contracts in general. Thus, in view of the head provision of Article 7 of the Federal Constitution, this provision is unconstitutional, based on the principle that there cannot be social regression in labor matters. ${ }^{22}$

Note that article 507-B says nothing regarding the gratuitousness of this provision of accounts to be made before the unions nor about the loss by the unions of their main source of income (due to the cessation of the mandatory payment of union dues). Thus, unions will be potentially free to charge fees for these new services, which will certainly be object of much criticism and discussion.

In our opinion, due to the constitutional principle of access to justice and judicial review (article 5, XXXV), the principle that orients Labor Law and the assumption regarding the absence of free will if workers are called to sign such annual release agreements, this document cannot be used to forgive employers who make payments

21 CASSAR, Vólia Bomfim; BORGES, Leonardo Dias. Comentários à reforma trabalhista. Rio de Janeiro: Forense; São Paulo: Método, 2017, p. 65.

22 LISBÔA, Daniel. Desacertos da quitação trabalhista: a vontade contemporânea e a quitação civil. In: FELICIANO, Guilherme Guimarães; TREVISO, Marco Aurélio Marsiglia; FONTES, Saulo Tarcísio de Carvalho (Org.). Reforma trabalhista: visão, compreensão e crítica. São Paulo: LTr, 2017, p. 163. 
incorrectly or insufficiently, or who seek to use such a procedure in order to avoid probable adverse judgments in Labor Courts.

\subsection{General discharge in Voluntary Redundancy Plans (article 477-B, of the CLT)}

The Labor Reform added to the text of the CLT an understanding already adopted in 2015 by the Full Bench of the STF:

An out-of-court settlement regarding the termination of the employment contract due to the employee's voluntary adherence to a voluntary redundancy program entails a full and general release from all payments in the employment contract, if this condition is expressly included in the collective agreement that approved the plan, as well as all other arrangements agreed with the employers. ${ }^{23}$

Law No. 13,467/2017 included the following article in the CLT:

Article 477-B. Voluntary Redundancy Program for individual, multiple employees or collective dismissal, provided for in collective bargaining agreements or collective labor agreements, entails a full and general release from the rights resulting from the employment relationship, except when agreed to otherwise by the parties.

Therefore, as long as the Voluntary Redundancy Program (a program that offers advantages and consideration for employees that leave the company) results from collective negotiation and is duly provided for in a collective agreement or collective bargaining agreement subscribed to by the workers' union, the employee's voluntary and spontaneous adherence to such a program entails a full, general and irrevocable release from the rights arising from the employment contract. This means that the employee will have no further claims following the termination of the employment contract.

\subsection{Collective or multiple dismissals without the need for previous negotiation with the employee's union (article 477-A of the CLT)}

Article 477-A was added to the CLT stating that collective

23 STF (Brazilian Supreme Court), Sitting en banc, Extraordinary Appeal 590,415/SC, Justice-Rapporteur Luís Roberto Barroso, judged on April 30, 2015. 
dismissals or multiple employee dismissals do not depend on previous negotiation with the workers' unions, as occurs in individual dismissals.

A collective dismissal is the dismissal of a large number of workers for the same reason: the company's need to reduce employee numbers due to economic, technological, structural or related reasons.

Multiple employee dismissal is the dismissal of several employees at the same time, but for specific reasons, related to each employee's specific conduct, which is to say, there is no common motive for the different individual or singular dismissals.

Article 477-A of the CLT provides that neither collective nor multiple employee dismissals depend on prior communication or negotiation with the workers' union:

Article 477-A. Groundless individual, collective or multiple employee dismissals are considered equivalent for all intents and purposes, and there is no need for previous authorization by the union or the execution of a collective bargaining agreement or collective labor agreement for their effectiveness.

This article tends in the opposite direction of the prevailing understanding of the Brazilian Labor Courts, including the Superior Labor Court, which required prior collective negotiation before mass dismissals. ${ }^{24}$

It also tends in the opposite direction of the ILO Convention 158. It should be pointed out that Brazil has ratified Convention 158 and has incorporated its terms into Brazilian legislation by Decree No. 1855/1996. However, soon afterwards, the Brazilian Government denounced this Convention through an act registered before the ILO on November 11, 1996. To date, the Action for a Declaration of Unconstitutionality No. 1625-3 challenging the validity of said denunciation is pending trial before the STF.

Despite the statements of article 477-A of the CLT, cases have been filed in the courts and there is already a debate as to whether this new provision of the CLT is valid and constitutional.

\subsection{Moral damages (article 223-A and following of the CLT)}

The question of moral damages is one of the most controversial ones regarding the Labor Reform bill and merits specific and thorough analysis, which goes beyond the scope of this study.

However, one important aspect regarding Collective Labor Law should be noted. According to the changes introduced by Law No.

24 TST (Brazilian Superior Labor Court), SDC, RODC 309/2009-000-15-00.4, Labor Justice Rapporteur Mauricio Godinho Delgado, DEJT: April 9, 2009. 
$13,467 / 2017$, new article 223-B of the CLT states that the aggrieved individual or legal entity is entitled to damages:

Article 223-B. An action or omission that offends the moral or existential sphere of an individual or legal entity causes material damage and shall exclusively entitle such persons to the right to compensation.

This article apparently intended to restrict the right to damages to the directly aggrieved individual or legal entity, excluding collective moral damages (when a group of people is aggrieved) as well as reflexive moral damages, when a person's right is damaged and such damage affects other people who live intimately, or have an affective relationship, with the aggrieved person (e.g. occupational accidents that cause workers' deaths and where family members seek compensation for possible moral damages).

In view of the special protection granted by the Constitution to the dignity of the individual and the social value of work (article 1, III and IV, and article 170), and provisions regarding damages set forth in article 5, X, of the Constitution, article 6, VI, of Law No. 8,078/80, and article 1, IV and V, of Law No. 7,347/85, it is understood that the wording conferred by Law No. 13,467/2017 on article 223-B of the CLT does not exclude the possibility of awarding collective work-related compensation for pain and suffering.

Moreover, since the Constitution (article 5, X) ensures, without limitation, the right to damages to whomever is aggrieved (directly or indirectly), in addition to affirming that the law shall not exclude consideration by the judicial branch of harm or threat to a right (article 5, XXXV), it is understood that the Labor Reform did not exclude the right to reflexive moral damages sustained by persons living closely to,

or having a close affective relationship with, the direct victim.

\subsection{Outsourcing (amendments to Law No. 6,019/1974)}

Although a thorough analysis of this subject is also beyond this study's scope, it should be noted that the Labor Reform allowed the outsourcing of any activity, including the company's main activity, according to article 4-A of Law No. 6,019/1974:

Article 4-A. Outsourcing is considered as the transfer by the contracting party of the performance of any of its activities, including its main activity, to a private legal entity that renders services and 
possesses economic capacity compatible with the performance of such activities. (Wording by Law No. 13,467/2017)

In other words, employees from external companies are now allowed to provide all services. For example, a school may now choose not to have any direct employees and to hire an outsourcing company to provide the teachers, inspectors, receptionists, doormen and cleaners necessary to render the services.

The Labor Reform bill (Law No. 11,467/2017) enacted these changes by amending Law No. 6,019/1974, which previously only provided for temporary work.

These changes represent a huge backward step and will damage employment relationships.

It should be noted that the new wording of the law (article 4-C of Law No. 6,019/1974) does not even ensure equal pay for the contracting company's direct employees and the outsourced employees, even if they perform identical activities at the same workplace, in violation of the provision of the Universal Declaration of Human Rights (UN, 1948 ) in its article 23.1. According to this article, equal pay is only a choice, not an obligation:

Article 4-C. (...) paragraph 1. Contracting party and outsourcing company may establish, if they so wish, that the outsourcing company's employees be entitled to payment equal to that received by the contracting party's employees, in addition to other rights not foreseen herein. (Added by Law No. 13,467/2017)

Understandable, this amendment has been object of harsh criticism, such as that expressed by FÁBIO VILLELA:

(...) it is now been shamelessly authorized to lease out labor, as if an outsourced worker were merchandise or commercial property. The human being is being reduced to the status of a material object in employment relations.

Thus, it is now possible to open companies without employees or even for workers to coexist in the same environment and perform the same activities, but receive different treatment, in flagrant violation 


\section{of the principle of equal protection (...). ${ }^{25}$}

With regard to Collective Labor Law, it should be pointed out that outsourced companys' employees are, in principle, affiliated with unions that are different from those of employees working directly for the companies where they perform their activities.

This fact will create further inequality between workers who perform identical activities for the same company, since the rights and benefits foreseen in collective agreements or collective bargaining agreements executed with the respective labor unions will be different.

\section{CONCLUSION AND FUTURE PERSPECTIVES}

This study is not comprehensive and does not cover all the issues included in the 2017 Labor Reform bill. Some equally important aspects - such as the creation of so-called "intermittent employment contracts" and the possibility of the termination of employment contracts by "mutual agreement" between the parties - were not even mentioned here, likewise changes regarding Procedural Labor Law and the new rules applicable to judicial resolution of labor claims.

However, the issues included here demonstrate that the Labor Reform bill enacted by Law No. 13,467/2017 has a strongly liberal tendency and seeks to give prevalence to rules negotiated by the parties themselves (both in the collective and individual sphere) over statutory rules. In other words, the reform clearly aims at reducing government interference in employment relationships.

They represent a clear effort, regarding employment relationships, in order to leave the public into the private sector, which is - in some ways - highly risky in a country still marked by extreme social inequality and where workers generally do not negotiate on equal terms with the other contracting party.

It is also evident that the Labor Reform, in many regards, sought to challenge prevailing precedents of the Superior Labor Court.

The possibility of outsourcing all of a company's activities (amendment to Law No. 6,019/1974) will produce potentially adverse consequences that represent an affront to the principle of equal pay (equal pay for equal work), and may cause a deterioration in employment relations.

Throughout the swift processing and approval of the Labor Reform in the Brazilian Congress, the government alleged that the CLT

25 VILLELA, Fábio Goulart. A terceirização na reforma trabalhista: a "legalização" da intermediação de mão de obra. In: TUPINAMBÁ, Carolina; GOMES, Fábio Rodrigues (Coord.). A reforma trabalhista: o impacto nas relações de trabalho. Belo Horizonte: Fórum, 2018, p. 153. 
was "old" and was one of the causes of the high unemployment rate and the country's huge number of labor claims. The government stated the need for "modernization" in order to improve employment opportunities, income and economic development. Such claims, however, have no empirical or scientific basis ${ }^{26}$, despite being repeated like mantras.

Although the 2017 Labor Reform may seem, in many regards, to be a backward step regarding the protection of social and labor rights, the information contained in this study is not intended to cast Brazil in a negative light or as representing a negative view of the country's future.

If, on the one hand, the Reform is considered a regression, on the other hand, in recent decades, institutions like the Labor Prosecutor's Office and Labor Inspection Agencies have become much stronger, better prepared and better organized. They have also hired more staff and gained greater autonomy.

Labor Prosecutors and Labor Inspectors already play - and will continue to play - a very important role in monitoring the main challenges in the labor sector, including the guarantee of dignity in the workplace.

Over the last thirty years, ideas regarding the recognition of the effectiveness, normative strength and binding nature of constitutional rules have gained strength, which is extremely important. All areas of Brazilian Law are now governed and construed in accordance with the rules and principles of the 1988 Constitution, including the Labor Law and Procedural Labor Law.

According to Justice Luís RoBerto BARroso, the emergence of a constitutional feeling in the country - creating a sense of respect and even affection towards the Constitution - must be celebrated. ${ }^{27}$

So, some legal provisions included in the Labor Reform should be read and interpreted according to the rules and principles of the 1988 Constitution and to International Conventions ratified by Brazil.

Brazil currently possesses a well-developed structure for resolving labor claims, with specialized and independent Labor Courts and Judges.

The Brazilian Supreme Court has performed a consistently important and admirable role as the guardian of the Constitution, including in Labor Law matters.

Despite its many challenges, Brazil has overcome difficult periods in the past, including dictatorships. But, inspired by the 1988 Constitution, Brazilian society is being built on republican and

26 FRAGALE FILHO, Roberto; SIQUEIRA NETO, José Francisco. Reforma trabalhista: uma cartografia das discussões equivocadas, esquecidas e frustrantes. In: TUPINAMBÁ, Carolina; GOMES, Fábio Rodrigues (Coord.). A reforma trabalhista: o impacto nas relações de trabalho. Belo Horizonte: Fórum, 2018, p. 425-426.

27 BARROSO, Luís Roberto. Op. cit., p. 322. 
democratic values.

Brazil has made significant progress in reducing child labor and eliminating degrading working conditions, thanks to the important work performed by the Labor Prosecutor's Office, the Labor Inspection Agencies, Police, Unions and the Courts.

Among many other issues, the country has made progress in regulating domestic employment relationships, student internships, prior notice in the termination of employment contracts without cause, and parental protection issues (including adoption).

The same applies to other areas, such as the fight to reduce corruption, inflation rates and extreme poverty.

According to the former President of the Brazilian Supreme Court, Justice Carlos Ayres BritTo, "democracy does not win by knockouts, it wins on points, it is a process...The implementation of Democracy is gradual." 28

Despite the challenges and obstacles along the way, we believe that Brazil remains resolute in its arduous and daily struggle to consolidate its democracy.

Japanese use to say that it is necessary to work hard and tirelessly - with focus, patience and resilience - in order to overcome difficulties and, thus, to achieve important goals.

As the Japanese say，ローマは一日にしてならず (Ro-ma wa ichinichi ni shite narazu).

In other words, "Rome wasn't built in a day."

The same principle applies to the Brazilian Democracy.

\section{REFERENCES}

AZEVEDO NETO, Platon Teixeira de. (Comentários ao art. 578 da CLT). In: RODRIGUES, Deusmar José (Coord.). Lei da reforma trabalhista: comentada artigo por artigo. Leme/SP: JH Mizuno, 2017, p. 221-224.

BARROSO, Luís Roberto. $O$ direito constitucional e a efetividade de suas normas, 6. ed. atualizada. Rio de Janeiro: Renovar, 2002.

BRITTO, Carlos Ayres. Carlos Ayres Britto: interview [May 2017]. Interviewer: Pedro Bial. São Paulo: Globo, 2017. Interview aired on May 22, 2017, in the TV program "Conversa com Bial”.

CASSAR, Vólia Bomfim; BORGES, Leonardo Dias. Comentários à reforma trabalhista. Rio de Janeiro: Forense; São Paulo: Método, 2017.

28 BRITTO, Carlos Ayres. Carlos Ayres Britto: interview [May 2017]. Interviewer: Pedro Bial. São Paulo: Globo, 2017. Interview aired on May 22, 2017 in TV program "Conversa com Bial". 
CONSELHO NACIONAL DE JUSTIÇA. Justiça em números 2017: ano-base 2016. Brasília: CNJ, 2017.

CONSOLIDATION OF LABOR LAWS. Available at https://web. archive.org/web/201011 0703 0918/http://natlaw.com/interam/ar/lb/tn/ tnarlb5.htm. Access on December 21, 2017.

DELGADO, Mauricio Godinho. Curso de Direito do Trabalho, 11. ed. São Paulo: LTr, 2012.

EDELMAN, Bernard. A legalização da classe operária. Trad. Marcus Orione. São Paulo: Boitempo, 2016.

FRAGALE FILHO, Roberto; SIQUEIRA NETO, José Francisco. Reforma trabalhista: uma cartografia das discussões equivocadas, esquecidas e frustrantes. In: TUPINAMBÁ, Carolina; GOMES, Fábio Rodrigues (Coord.). A reforma trabalhista: o impacto nas relações de trabalho. Belo Horizonte: Fórum, 2018, p. 415-428.

GARCIA, Gustavo Filipe Barbosa. Reforma trabalhista, 2. ed. Salvador: Juspodivm, 2017.

GOYOS JÚNIOR, Durval de Noronha. Dicionário jurídico Noronha: inglês-português, português-inglês, 6. ed. São Paulo: Observador Legal, 2006.

IBRAHIM, Fábio Zambitte. A previdência social no estado contemporâneo: fundamentos, financiamento e regulação. Niteroi: Impetus, 2011.

LISBÔA, Daniel. Desacertos da quitação trabalhista: a vontade contemporânea e a quitação civil. In: FELICIANO, Guilherme Guimarães; TREVISO, Marco Aurélio Marsiglia; FONTES, Saulo Tarcísio de Carvalho (Org.). Reforma trabalhista: visão, compreensão e crítica. São Paulo: LTr, 2017, p. 149-167.

MELEK, Marlos Augusto. Trabalhista! E agora? Onde as empresas mais erram. Curitiba: Estudo Imediato, 2016.

MELLO, Maria Chaves de. Portuguese-English - English-Portuguese - Law dictionary, 10. ed. Rio de Janeiro: Forense; São Paulo: Método, 2012 .

PALOMEQUE LOPEZ, Manuel Carlos. Direito do Trabalho e ideologia. Coimbra: Almedina, 2001.

SILVA, Homero Batista Mateus da. Comentários à reforma trabalhista. São Paulo: Revista dos Tribunais, 2017, p. 70.

THE FEDERAL SENATE, Undersecretariat of Technical Publications. Constitution of the Federative Republic of Brazil: Constitutional text of October 5, 1988, with the alterations introduced by Constitutional 
Amendments no. 1/92 through 72/2013 and by Revision Constitutional Amendments no. 1/94 through 6/94, translated and revised by Istvan Vajda, Patrícia de Queiroz Carvalho Zimbres, Vanira Tavares de Souza, 6th rev. ed. Brasilia: The Federal Senate, 2013.

TRIBUNAL SUPERIOR DO TRABALHO, Coordenadoria de Estatística e Pesquisa. Relatório geral da Justiça do Trabalho 2016. Brasília: TST, 2017.

, Notícias do TST. "Processos recebidos na Justiça do Trabalho já são 100\% eletrônicos". Disponível em http://www.tst.jus.br/noticias/-/ asset_publisher/89Dk/content/id/ 24446854. Acesso em 20/10/2017.

VERÇOSA, Fabiane. Arbitragem para a resolução de conflitos trabalhistas no Direito brasileiro. In: MELO, Leonardo de Campos; BENEDUZI, Renato Resende (Coord.). A reforma da arbitragem. Rio de Janeiro: Forense, 2016, p. 483-502.

VIANNA, Luiz Werneck. Liberalismo e sindicato no Brasil, 3. ed. Rio de Janeiro: Paz e Terra, 1978.

VILLELA, Fábio Goulart. A terceirização na reforma trabalhista: a "legalização" da intermediação de mão de obra. In: TUPINAMBÁ, Carolina; GOMES, Fábio Rodrigues (Coord.). A reforma trabalhista: o impacto nas relações de trabalho. Belo Horizonte: Fórum, 2018, p. 147-160. 